\title{
THE INFLUENCE OF IRRIGATION WITH INTENSIVE FISH FARM WATER ON THE QUALITY INDICATORS OF AEROBIC RICE (Oryza sativa L.)
}

\author{
IBADZADE, M. $.^{1,2^{*}}-$ KUN, Á. $^{1}-$ SZÉKELY, Á. ${ }^{1}-$ SZALÓKI, T. ${ }^{1}-$ PENKSZA, K. $^{2}-$ JANCSÓ, M. $^{1}$ \\ ${ }^{I}$ Research Institute of Irrigation and Water Management, National Agricultural Research and \\ Innovation Centre, Anna liget u. 35, H-5540 Szarvas, Hungary \\ ${ }^{2}$ Faculty of Agricultural and Environmental Sciences, Szent István University, Páter Károly u. \\ 1., H-2100 Gödöllö, Hungary \\ ${ }^{*}$ Corresponding author \\ e-mail: marks.ibadzade@gmail.com; phone: +36-70-245-0463
}

(Received $2^{\text {nd }}$ Mar 2020; accepted $7^{\text {th }}$ Jul 2020)

\begin{abstract}
This study examined the effect of effluent water from an intensive fish farm on rice (Oryza sativa L.) grown under aerobic condition in Hungary. During the experiment four treatments were used: $\mathrm{T}_{1}$ - effluent water; $\mathrm{T}_{2}$ - effluent water supplemented with gypsum; $\mathrm{T}_{3}$ - effluent water diluted with surface water and supplemented with gypsum; $\mathrm{T}_{\mathrm{C}}$ - control treatment. A number of quality parameters (TKW thousand kernel weight, MQP - milling quality parameters, MC - mineral content) of the selected Hungarian rice variety (M 488) were studied. While, in the TKW test no statistically significant difference was found between the treatments, MQP test showed that there was a statistically significant difference between treatments in the percentage of whole polished (white) rice. The highest percentage was in $\mathrm{T}_{\mathrm{C}}$ with $68.5 \%$, $\mathrm{T}_{1}, \mathrm{~T}_{2}$, and $\mathrm{T}_{3}$ had $60 \%, 61.1 \%$ and $59.12 \%$, respectively. The analytical analysis of MC highlighted, that the $\mathrm{Ca}$ and Na contents in rice seeds were not affected by the treatments, however, under $\mathrm{T}_{3}$ a statistically significant decrease in the $\mathrm{P}, \mathrm{K}$ and $\mathrm{Mg}$ contents of rice seeds was observed. Altogether, irrigation with fish farm water affects some quality parameters of the chosen rice variety in different ways, this effect can remain stable while reducing stress levels.
\end{abstract}

Keywords: effluent water, environment, rice quality, water saving, water stress

\section{Introduction}

One of the necessary conditions for obtaining a high quality crop is associated with water quality that meets the standards of irrigation (Suarez, 2011; Limjuco et al., 2016). Currently, climate change and water scarcity make it difficult for farmers to access quality irrigation water (Deressa et al., 2011; Chand and Kumar, 2018). These are undesirable limiting stress factors for the growth, development, and productivity of plants (Wang et al., 2006). Stresses, such as drought and high salinity in irrigation water can damage life cycle of plants, change cell size, disrupt gas exchange, and ultimately reduce yield (Bongi and Loreto, 1989; Rhodes and Nadolska-Orczyk, 2001; Tenhaken, 2015; Chowdhury, 2016; Joshi et al., 2016; Dresselhaus and Huckelhoven, 2018).

Many researchers have focused on alternative resources, such as wastewater in order to eliminate the existing shortage and to provide plants with the necessary water in a timely manner (Haruvy, 1997; Toze, 2006; Drechsel and Evans, 2010). Since they are rich in chemical composition, in some cases, these waters can be used as fertilizers (Rahimi et al., 2012; Ryu et al., 2012). It is also possible to make some progress in increasing productivity through the use of wastewater for irrigation (Khan et al., 2009). Another progressive aspect of this is the opportunity of reuse of wastewater, which in most cases is directly discharged into rivers, seas and oceans (Nair, 2008; Kamal et al., 
2008). Eventually, this reuse will lead to environmental protection and minimization of potential damage. For instance, in recent decades, it was noted that an increase in the number of fish farms due to the disposal of waste into natural water resources has led to a disruption in the chemical and environmental balance of the water (Jones, 1990). According to a study by Ruiz-Zarzuela et al. (2009) in Northeast Spain, water from fish farms leads to a decrease in $\mathrm{pH}$ and dissolved oxygen in the river, which could affect water quality and aquatic life. However, the application of effluent water from fish farms in agriculture may be more suitable. According to Castro et al. (2006) the application of effluents from fish ponds greatly increased tomato yields in Northeast Brazil. Abdelraouf et al. (2014) reported in their study in Egypt, drainage water of fish ponds could be a good option for saving current water resources.

Changes at the global level, as well as existing problems also affect rice (Oryza sativa L.) cultivation. Rice is one of the most water-demanding crops among cereals and is the main agricultural crop that satisfies the nutritional needs of a large part of the world's population (Vergara, 1991; Muthayya et al., 2014). In addition, as the number of people increases, the demand for this product increases too (Khush, 2005). According to some researchers, the use of aerobic rice systems, which is considerably more water-efficient than the traditional method, can be an advantageous method in conditions of water scarcity (Bouman et al., 2002; Pinheiro et al., 2006). But another important factor in this event is related to the quality and yield of rice. Thus, in this study, our aim was to identify the effect of effluent water from fish farm on the development of aerobic rice by studying the qualitative characteristics and parameters of the mineral composition. In addition, we also focused on taking another step to the reduction of water demand and environmental pollution to improve a complex agricultural system.

\section{Materials and methods}

The experiment was conducted at the National Agricultural Research and Innovation Centre, Research Institute of Irrigation and Water Management (NAIK ÖVKI) Lysimeter

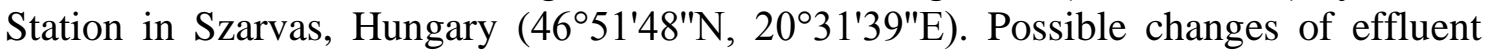
water from the intensive catfish farm on rice was explored during the experiment. For that purpose Hungarian rice variety named M 488 was planted in 16 gravitation lysimeters under aerobic condition in May 2019. The treatments were applied by a micro sprinkler irrigation method and with four replications. The applied experimental design has been shown in Figure 1. Generally, lysimeters are devices used to study the dynamics of water, evapotranspiration and changes of other substances in the soil (Lanthaler, 2004). However, the reason for choosing gravitation lysimeter was to create aerobic conditions for the plants and at the same time to separate them from the vertical and horizontal effects of the surrounding environment and soil.

The non-weighted, backfilled gravitation lysimeters at the NAIK ÖVKI have the volume of $1 \mathrm{~m}^{3}$ and each of them has a surface of 1 squaremeter. Four lysimeters were installed into one block together (one treatment in irrigation studies). The bottom $10 \mathrm{~cm}$ of the lysimeter is a layer of gravel to collect percolated water in case of heavy rain or high amount of irrigation. The plants have $80 \mathrm{~cm}$ of soil for the development. The type of soil in the lysimeters was vertisol (expansive clay). The plant density was set to 40 plants $/ \mathrm{m}^{2}$ (Figure 2). 


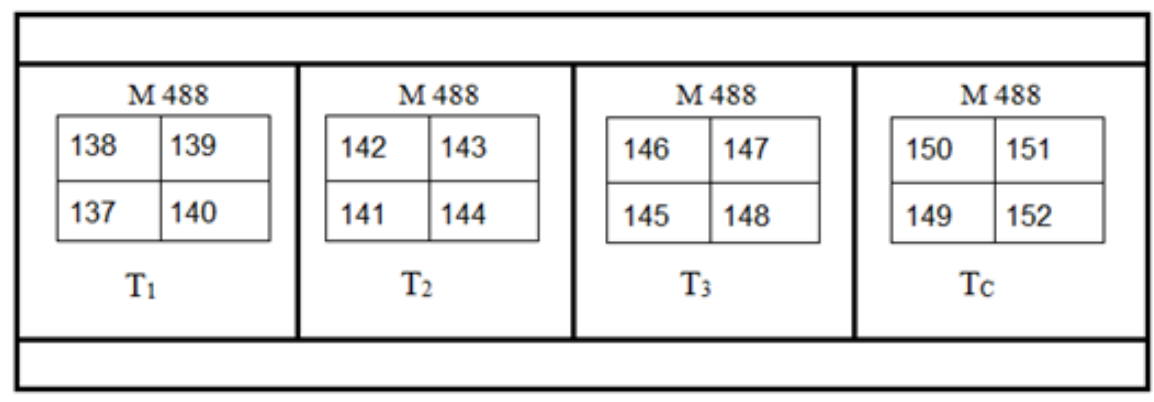

Figure 1. The applied experimental design. $T_{1}$ - effluent water, $T_{2}$ - effluent water supplemented with gypsum, $T_{3}$ - effluent water mixed with surface water and supplemented with gypsum, $T_{C}-$ river water (control). The numbers in the cells represent the identification number of the gravitational lysimeters. M 488 - Hungarian rice variety

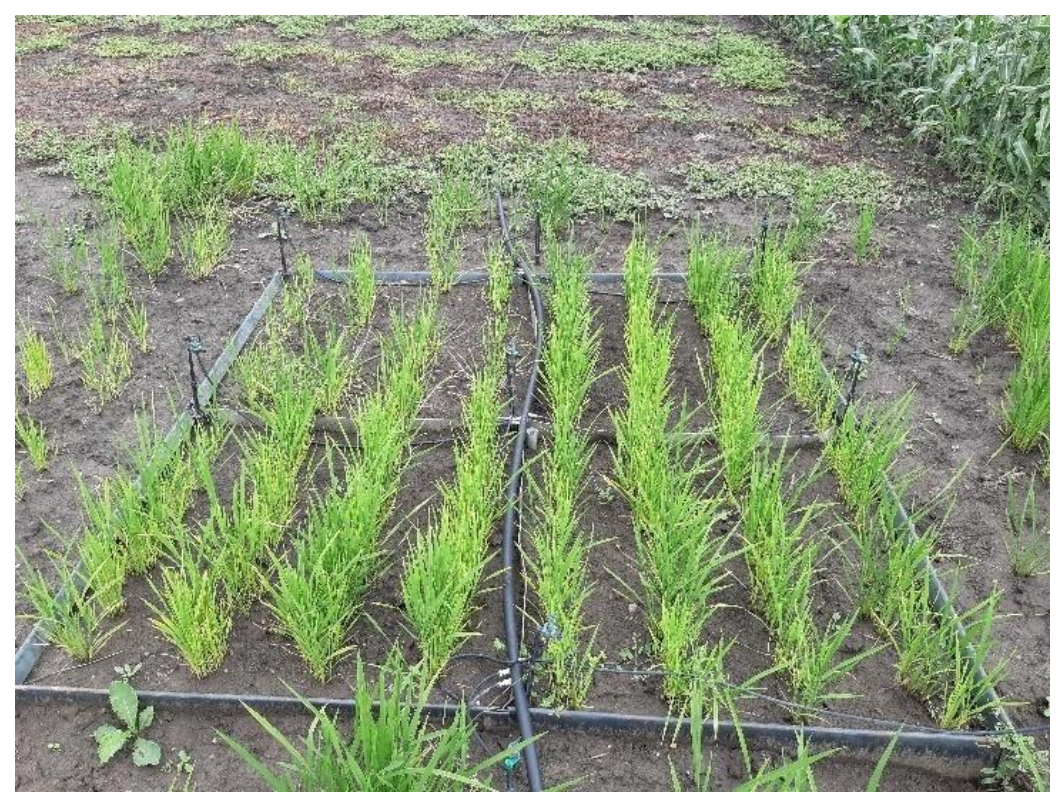

Figure 2. Lysimeter experiment of rice developed with different quality of irrigation water

Four types of treatments have been applied during the experiment: $\mathrm{T}_{1}$ - effluent water; $\mathrm{T}_{2}$ - effluent water supplemented with gypsum; $\mathrm{T}_{3}$ - effluent water diluted with surface water and supplemented with gypsum; $\mathrm{T}_{\mathrm{C}}$ - control treatment, water from oxbow, which is a section of the Körös River in eastern Hungary. The chemical parameters of treatments are listed in the Table 1.

Seeds were sown on May 22, 2019. On the first and second irrigation days $\left(22^{\text {nd }}\right.$ of May and $7^{\text {th }}$ of June) all plants in lysimeters were irrigated with river water, only after that they were irrigated on the basis of treatments. On July $4,0.5 \mathrm{~kg}$ of fertilizer $\left(\mathrm{NH}_{4} \mathrm{NO}_{3}+\mathrm{CaMg}\left(\mathrm{CO}_{3}\right)_{2}\right)$ was applied $\left(84.4 \mathrm{~kg} \mathrm{~N}^{*} \mathrm{ha}^{-1}\right)$, and pesticides were not used during the experiments. The total applied irrigation water was $200 \mathrm{~mm}$. Irrigation time and amount of used water are shown in the following Table 2.

Meteorological data were measured using meteorological equipment (Agromet-Solar automatic weather station, Boreas Ltd., Hungary) that was installed next to the experimental field. Rainfall during the growing season was $303.7 \mathrm{~mm}$ (Table 3). 
Table 1. The basic chemical parameters of treatments

\begin{tabular}{c|c|c|c|c}
\hline Chemical parameters & $\mathbf{T}_{\mathbf{1}}$ & $\mathbf{T}_{\mathbf{2}}$ & $\mathbf{T}_{\mathbf{3}}$ & $\mathbf{T}_{\mathbf{C}}$ \\
\hline $\mathrm{pH}$ & 7.77 & 7.71 & 7.70 & 7.55 \\
Electrical Conductivity $(\mathrm{EC})(\mu \mathrm{S} / \mathrm{cm})$ & 1180 & 1905.00 & 1033.75 & 371.86 \\
m-alkalinity & 13.77 & 14.65 & 8.23 & 3.00 \\
Bicarbonate $(\mathrm{mg} / \mathrm{l})$ & 838.67 & 894.00 & 502.00 & 182.67 \\
Ammonium-N (mg/l) & 20.40 & 23.45 & 10.39 & 0.37 \\
Nitrate-N (mg/l) & 0.03 & - & 0.47 & 0.43 \\
Nitrite-N (mg/l) & 0.02 & 0.13 & 0.13 & 0.06 \\
Total inorganic N (mg/l) & 20.45 & 23.58 & 10.60 & 0.64 \\
Total organic N (mg/l) & 5.86 & 4.98 & 2.51 & - \\
Total N (mg/l) & 26.3 & 28.55 & 13.10 & 1.19 \\
P-orthophosphate (mg/l) & 1.72 & 2.55 & 1.38 & 0.12 \\
Total P (mg/l) & 2.18 & 2.67 & 1.53 & 0.15 \\
Chloride (mg/l) & 29.90 & 33.15 & 27.15 & 22.54 \\
Sulphate (mg/l) & 32.65 & 448.75 & 164.18 & 34.58 \\
Ca (mg/l) & 23.23 & 187.50 & 90.83 & 39.04 \\
Mg (mg/l) & 10.08 & 11.02 & 10.69 & 9.80 \\
Na (mg/l) & 249.00 & 266.75 & 131.25 & 28.90 \\
K (mg/l) & 6.08 & 6.61 & 5.43 & 3.71 \\
\hline
\end{tabular}

$\mathrm{T}_{1}$ - effluent water, $\mathrm{T}_{2}$ - effluent water supplemented with gypsum, $\mathrm{T}_{3}$ - effluent water mixed with surface water and supplemented with gypsum, $\mathrm{T}_{\mathrm{C}}$ - river water (control)

Table 2. Irrigation dates and amount of applied water

\begin{tabular}{|c|c|c|c|c|c|c|c|c|c|c|c|}
\hline & \multicolumn{11}{|c|}{ Irrigation water applied (mm) } \\
\hline $\begin{array}{c}\text { Irrigation } \\
\text { dates }\end{array}$ & $\begin{array}{l}22 . \\
\text { May }\end{array}$ & $\begin{array}{c}07 . \\
\text { June }\end{array}$ & $\begin{array}{l}14 . \\
\text { June }\end{array}$ & $\begin{array}{r}02 . \\
\text { July }\end{array}$ & $\begin{array}{l}04 . \\
\text { July }\end{array}$ & $\begin{array}{l}12 . \\
\text { July }\end{array}$ & $\begin{array}{c}18 . \\
\text { July }\end{array}$ & $\begin{array}{l}26 . \\
\text { July }\end{array}$ & $\begin{array}{c}12 . \\
\text { August }\end{array}$ & $\begin{array}{c}22 . \\
\text { August }\end{array}$ & Total \\
\hline $\mathrm{T}_{1}$ & $\underline{20}$ & $\underline{20}$ & 20 & 20 & 20 & 20 & 20 & 20 & 20 & 20 & 200 \\
\hline $\mathrm{T}_{2}$ & $\underline{20}$ & $\underline{20}$ & 20 & 20 & 20 & 20 & 20 & 20 & 20 & 20 & 200 \\
\hline $\mathrm{T}_{3}$ & $\underline{20}$ & $\underline{20}$ & 20 & 20 & 20 & 20 & 20 & 20 & 20 & 20 & 200 \\
\hline $\mathrm{T}_{\mathrm{C}}$ & 20 & $\underline{20}$ & 20 & 20 & 20 & 20 & 20 & 20 & 20 & 20 & 200 \\
\hline
\end{tabular}

$\mathrm{T}_{1}$ - effluent water, $\mathrm{T}_{2}$ - effluent water supplemented with gypsum, $\mathrm{T}_{3}$ - effluent water mixed with surface water and supplemented with gypsum, $\mathrm{T}_{\mathrm{C}}$ - river water (control)

Table 3. Monthly precipitations and temperatures (average, minimum and maximum) during the growing season

\begin{tabular}{c|c|c|c|c}
\hline & Precipitation $(\mathbf{m m})$ & T avg. $\left({ }^{\circ} \mathbf{C}\right)$ & T min. $\left({ }^{\circ} \mathbf{C}\right)$ & T max. $\left({ }^{\circ} \mathbf{C}\right)$ \\
\hline May & 48.7 & 17.8 & 8.0 & 26.0 \\
June & 162.4 & 23.5 & 14.2 & 34.0 \\
July & 68.1 & 22.2 & 10.3 & 34.1 \\
August & 24.5 & 24.1 & 10.8 & 36.3 \\
\hline
\end{tabular}

After the harvest $\left(24^{\text {th }}\right.$ of September, 2019) and standard post-harvest operation (cleaning, drying, and storing) basic tests - Thousand Kernel Weight (TKW), Milling Quality Parameters (MQP) and Mineral Content (MC) of rice seeds were analysed (Table 4). 
Table 4. Conducted test and used equipments

\begin{tabular}{c|c|c}
\hline № & Conducted tests & Used equipments (methods) \\
\hline 1 & Moisture content & Sartorius MA45 \\
2 & Thousand Kernel Weight (TKW) & 1) Sartorius BP221S \\
3 & Milling Quality Parameters (MQP) & 2) Satake THU Laboratory Husker \\
& & Satake TM05 Test Mill laboratory \\
4 & Analysis of Mineral Content (MC) & 1) Thermo Scientific Solaar M6 atomic absorption \\
& & 2) Thectrophotometer \\
\hline
\end{tabular}

In order to begin those tests, moisture content of rice seeds from every sample was defined. At the beginning, the grains of each sample were divided into tiny particles, then by using Sartorius MA45 moisture analyser moisture content was found. The average moisture content was computed after the replications of four measurements.

For Thousand Kernel Weight (TKW) test, 100 paddy seeds were counted from each sample and weighed on Sartorius BP221S analytical balance. Afterwards, husk of seeds was removed by using Satake THU Laboratory Husker equipment and cargo (brown) rice weighed. The obtained results were multiplied by 10 . After four replications of tests, the average TKW of paddy and cargo rice was determined.

$100 \mathrm{~g}$ of rice from each sample was prepared for Milling Quality Parameter (MQP) analysis. First, a husk layer of seeds removed and cargo rice was weighed. Later, by using Satake TM05 Test Mill laboratory equipment brown rice was polished and the results were weighed. Subsequently, the percentage whole and broken white (polished) rice were calculated. The experiment was repeated five times and the average value is defined. According to the following formulas, the results were calculated (Lapis et al., 2019):

$$
\begin{gathered}
\% \text { Cargo rice }=\frac{\text { weight of brown rice }(g)}{\text { weight of paddy rice }(g)} * 100 \\
\% \text { Polished rice }=\frac{\text { weight of polished rice }(g)}{\text { weight of paddy rice }(g)} * 100 \\
\% \text { Whole p.rice }=\frac{\text { weight of whole price }(g)}{\text { weight of paddy rice }(g)} * 100
\end{gathered}
$$

Mineral Content (MC) test involves determination of amount basic minerals $(\mathrm{Ca}, \mathrm{Mg}$, $\mathrm{K}, \mathrm{Na}$, and $\mathrm{P}$ ) in rice grains. In order to carry on analyses, paddy rice from each sample were hulled with Satake THU Laboratory Husker and brown rice received. After standard

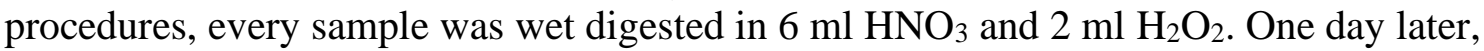
the samples were kept in a microwave oven at a temperature of $180{ }^{\circ} \mathrm{C}$ for 1.5 hours. Afterwards, samples were analysed by using AAS and ICP-OES (NAIK ÖVKI Laboratory of Environmental Analytics, Szarvas, Hungary).

Based on standard methods, $\mathrm{Ca}, \mathrm{Mg}, \mathrm{K}$ and $\mathrm{Na}$ content were measured by Thermo Scientific Solaar M6 atomic absorption spectrophotometer. Determination of $\mathrm{P}$ was done with Thermo Scientific ICAP 6000 ICP-OES inductively coupled plasma atomic emission equipment, according to MSZ EN ISO 11885:2000 international and Hungarian standard.

The collected data were subjected to the analysis of variance (ANOVA) using IBM SPSS software (version 22). The significant differences among mean values were 
determined with the Tukey test at 5\% level of probability. In condition of violation of homogeneity of variances (Levene's test, $\mathrm{p}<0.05$ ), Games-Howell post-hoc test was set under the terms of Welch test $(\mathrm{p}<0.05)$.

\section{Results and discussion}

\section{Moisture content}

The general idea behind of controlling moisture content of paddy seeds to receive moisture content below 14\% (International Rice Research Institute, 2013). For the experiments, samples were placed in storage room in unmonitored condition. Although, conducted experiments were done moisture free basis, in our experiments we also got results less than $14 \%$ in all samples. The moisture content of samples under $\mathrm{T}_{1}, \mathrm{~T}_{2}, \mathrm{~T}_{3}$ and $\mathrm{T}_{\mathrm{C}}$ was $7.97 \%, 7.46 \%, 7.69 \%, 7.28 \%$, respectively.

\section{Thosand Kernel Weight (TKW)}

One of the main indicators of the vitality, quality, and productivity of rice seeds is associated with TKW (Wu et al., 2018). In many cases, the TKW of rice grains in cultivation under flooding conditions is greater than in aerobic rice systems, however, it may vary depending on the rice cultivar (Castaneda et al., 2003; Reddy et al., 2010). The results of our experiments (Table 5) show, in both paddy seeds and cargo seeds, the highest TKW between treatments was observed with $\mathrm{T}_{1}$. Nevertheless, the result of statistical analysis indicated non-significant differences between treatments $(p>0.05)$. The absence of such a statistically significant difference specifies a similar reaction of rice to all treatments.

Table 5. Thousand kernel weight of paddy and cargo seeds of rice developed with different quality of irrigation (Szarvas, 2019)

\begin{tabular}{|c|c|c|c|}
\hline Treatment & & $\begin{array}{c}\text { TKW of paddy seed } \\
\text { (g) }\end{array}$ & $\begin{array}{c}\text { TKW of cargo seed } \\
\text { (g) }\end{array}$ \\
\hline $\mathrm{T}_{1}$ & $\begin{array}{c}\text { Average } \\
\text { CI }\end{array}$ & $\begin{array}{c}22.15 \mathrm{a} \\
{[21.54 ; 22.76]}\end{array}$ & $\begin{array}{c}17.88 \mathrm{a} \\
{[17.4 ; 18.35]}\end{array}$ \\
\hline $\mathrm{T}_{2}$ & $\begin{array}{l}\text { Average } \\
\text { CI }\end{array}$ & $\begin{array}{c}22.0 \mathrm{a} \\
{[20.88 ; 23.13]}\end{array}$ & $\begin{array}{c}17.68 \mathrm{a} \\
{[16.65 ; 18.72]}\end{array}$ \\
\hline $\mathrm{T}_{3}$ & $\begin{array}{l}\text { Average } \\
\text { CI }\end{array}$ & $\begin{array}{c}22.01 \mathrm{a} \\
{[21.65 ; 22.38]}\end{array}$ & $\begin{array}{c}17.76 \mathrm{a} \\
{[17.2 ; 18.32]}\end{array}$ \\
\hline $\mathrm{T}_{\mathrm{C}}$ & $\begin{array}{c}\text { Average } \\
\text { CI }\end{array}$ & $\begin{array}{c}21.48 \mathrm{a} \\
{[21.17 ; 21.78]}\end{array}$ & $\begin{array}{c}17.28 \mathrm{a} \\
{[17.19 ; 17.37]}\end{array}$ \\
\hline
\end{tabular}

$\mathrm{T}_{1}$ - effluent water, $\mathrm{T}_{2}$ - effluent water supplemented with gypsum, $\mathrm{T}_{3}$ - effluent water mixed with surface water and supplemented with gypsum, $\mathrm{T}_{\mathrm{C}}$ - river water (control). CI - confidence interval (lower and upper bound). Values with the same letter are not significantly different at $\mathrm{p}<0.05$

\section{Milling Quality Parameters (MQP)}

The importance of rice milling is mainly related to the percentage of whole white rice (Dhankhar et al., 2014). On the one hand, if it is connected with the tradition of consumption, on the other hand, it is closely connected with marketing goals (Dela Cruz and Khush, 2000; Zhou et al., 2019). Usually, most consumers before buying a product, 
pay attention not only to the shape of the rice, but also to the colour and aroma of the rice (Rachmat et al., 2006). While in our experiment in the analysis of cargo rice percentage and polished (white) rice percentage, apparent differences were not found, in the percentage of whole polished rice there were statistically significant differences between treatments (Table 6$) . \mathrm{T}_{1}, \mathrm{~T}_{2}$, and $\mathrm{T}_{3}$ had a statistically similar results $(\mathrm{p}>0.05), 60 \%, 61 \%$ and $59.12 \%$, respectively. However, the highest percentage of whole polished rice was observed in the control treatment $(68.5 \%)$ and this difference was statistically significant $(\mathrm{p}<0.05)$ between $\mathrm{T}_{1}, \mathrm{~T}_{2}$, and $\mathrm{T}_{3}$. According to the initial assumption, this difference between the results is due to the chemical composition between the control and the other treatments. One of the main indicators of the effluent water from intensive fish farm is that it contains a lot of sodium. Usually, rice cultivated under aerobic conditions and irrigated at regular intervals is subject to abiotic stresses (Jabran et al., 2017). This sensitivity to abiotic factors manifests itself as a reduction in a number of plant parameters (Singh et al., 2012; Kato and Katsura, 2014). The high salt content in the water prevents the plant from absorbing the water it needs (Ghosh et al., 2016). The greatest challenge is when the temperature is high, which causes the plant to become more stressed (Clermont-Dauphin et al., 2010; Mishra et al., 2015; Ali et al., 2019). Although the response to salinity may vary depending on the rice variety, increasing the salinity level of irrigation water at all stages of cultivation can significantly affect rice (Castillo et al., 2007; Fraga et al., 2010; Chang et al., 2019). This may ultimately affect the quality of the rice seeds.

Table 6. Milling quality parameters of cargo and polished seeds of rice developed with different quality of irrigation (Szarvas, 2019)

\begin{tabular}{c|c|c|c|c}
\hline \multirow{2}{*}{ Treatment } & & $\begin{array}{c}\text { Cargo (Brown) } \\
(\boldsymbol{\%})\end{array}$ & $\begin{array}{c}\text { Polished (White) } \\
(\boldsymbol{\%})\end{array}$ & $\begin{array}{c}\text { Whole polished rice } \\
(\boldsymbol{\%})\end{array}$ \\
\hline \multirow{2}{*}{$\mathrm{T}_{1}$} & Average & $79.2 \mathrm{a}$ & $72 \mathrm{a}$ & $60 \mathrm{a}$ \\
& CI & {$[78.16 ; 80.24]$} & {$[71.12 ; 72.88]$} & {$[54.81 ; 65.19]$} \\
$\mathrm{T}_{2}$ & Average & $78.2 \mathrm{a}$ & $71.1 \mathrm{a}$ & $61.1 \mathrm{a}$ \\
& CI & {$[77.65 ; 78.76]$} & {$[68.72 ; 73.48]$} & {$[58.14 ; 64.06$} \\
$\mathrm{T}_{3}$ & Average & $78.8 \mathrm{a}$ & $72.8 \mathrm{a}$ & $59.12 \mathrm{a}$ \\
& CI & {$[78.19 ; 79.41]$} & {$[72.19 ; 73.41]$} & {$[57.93 ; 60.31]$} \\
$\mathrm{T}_{\mathrm{C}}$ & Average & $78.8 \mathrm{a}$ & $72.9 \mathrm{a}$ & $68.5 \mathrm{~b}$ \\
& $\mathrm{CI}$ & {$[77.86 ; 79.74]$} & {$[71.29 ; 74.51]$} & {$[66.92 ; 70.08]$} \\
\hline
\end{tabular}

$\mathrm{T}_{1}$ - effluent water, $\mathrm{T}_{2}$ - effluent water supplemented with gypsum, $\mathrm{T}_{3}$ - effluent water mixed with surface water and supplemented with gypsum, $\mathrm{T}_{\mathrm{C}}$ - river water (control). CI - confidence interval (lower and upper bound). Values with the same letter are not significantly different at $\mathrm{p}<0.05$

Salinity also has a direct effect on the protein content of rice grains, where protein loss can increase the rice seed breakage (Leesawatwong et al., 2004; Balindong et al., 2018). Since the decrease in protein content in salt-sensitive rice varieties is observed more distinctly (Billah et al., 2017). Moreover, according to Rao et al. (2013), salinity in the soil is another reason for the decline in head rice recovery.

\section{Mineral Content (MC)}

The content of $\mathrm{Ca}$ in all treatments had a statistically similar ( $>>0.05)$ result (Table 7). Analogous results were also noted in $\mathrm{Na}$ content. While there was no statistically significant difference in $\mathrm{Mg}$ content between the control and $\mathrm{T}_{1}, \mathrm{~T}_{2}, \mathrm{~T}_{3}$, the difference 
between $T_{3}$ and $T_{1}, T_{2}$ was statistically significant $(p<0.05)$. $P$ and $K$ content in $T_{3}$ was lower compared to the control and $\mathrm{T}_{1}, \mathrm{~T}_{2}$, which was a statistically significant difference $(\mathrm{p}<0.05)$.

Table 7. Average mineral content in M 488 rice seeds, (Szarvas, 2019)

\begin{tabular}{|c|c|c|c|c|c|c|}
\hline Treatment & & $\begin{array}{c}\text { Ca } \\
\text { (mg/kg dry } \\
\text { matter) }\end{array}$ & $\begin{array}{c}\text { Mg } \\
\text { (mg/kg dry } \\
\text { matter) }\end{array}$ & $\begin{array}{c}P \\
\text { (mg/kg dry } \\
\text { matter) }\end{array}$ & $\begin{array}{c}\mathrm{K} \\
\text { (mg/kg dry } \\
\text { matter) }\end{array}$ & $\begin{array}{c}\mathrm{Na} \\
\text { (mg/kg dry } \\
\text { matter) }\end{array}$ \\
\hline $\mathrm{T}_{1}$ & $\begin{array}{c}\text { Average } \\
\text { CI }\end{array}$ & $\begin{array}{l}396.5 \mathrm{a} \\
{[306.71 ;} \\
486.29]\end{array}$ & $\begin{array}{c}1652.5 \mathrm{~b} \\
{[1573.07} \\
1731.93]\end{array}$ & $\begin{array}{c}4240 \mathrm{~b} \\
{[3954.47 ;} \\
4525.53]\end{array}$ & $\begin{array}{c}3600 \mathrm{~b} \\
{[3327.78 ;} \\
3872.22]\end{array}$ & $\begin{array}{c}200.25 \mathrm{a} \\
{[165.4 ; 235.1]}\end{array}$ \\
\hline $\mathrm{T}_{2}$ & $\begin{array}{c}\text { Average } \\
\text { CI }\end{array}$ & $\begin{array}{l}412.75 \mathrm{a} \\
{[338.41 ;} \\
487.09]\end{array}$ & $\begin{array}{c}1717.5 \mathrm{~b} \\
{[1657.43 ;} \\
1777.57]\end{array}$ & $\begin{array}{c}4490 \mathrm{~b} \\
{[4266.85} \\
4713.15]\end{array}$ & $\begin{array}{c}3807.5 b \\
{[3469.86} \\
4145.14]\end{array}$ & $\begin{array}{l}211.25 \mathrm{a} \\
\text { [181.02; } \\
241.48]\end{array}$ \\
\hline $\mathrm{T}_{3}$ & $\begin{array}{c}\text { Average } \\
\text { CI }\end{array}$ & $\begin{array}{c}421 \mathrm{a} \\
{[361.7 ; 480.3]}\end{array}$ & $\begin{array}{c}1405 \mathrm{a} \\
{[1364.96 ;} \\
1445.04]\end{array}$ & $\begin{array}{c}3440 \mathrm{a} \\
{[3293.58} \\
3586.42]\end{array}$ & $\begin{array}{c}3005 \mathrm{a} \\
{[2807.75} \\
3202.25]\end{array}$ & $\begin{array}{l}226.75 \mathrm{a} \\
{[208.92 ;} \\
244.58]\end{array}$ \\
\hline $\mathrm{T}_{\mathrm{C}}$ & $\begin{array}{c}\text { Average } \\
\text { CI }\end{array}$ & $\begin{array}{l}427.75 \mathrm{a} \\
{[369.83 ;} \\
485.67]\end{array}$ & $\begin{array}{c}\text { 1650ab } \\
{[1419.41 ;} \\
1880.59]\end{array}$ & $\begin{array}{c}4297.5 \mathrm{~b} \\
{[3469.62} \\
5125.38]\end{array}$ & $\begin{array}{c}3665 b \\
{[3217.85} \\
4112.15]\end{array}$ & $\begin{array}{l}201.25 \mathrm{a} \\
{[183.28} \\
219.22]\end{array}$ \\
\hline
\end{tabular}

$\mathrm{T}_{1}$ - effluent water, $\mathrm{T}_{2}$ - effluent water supplemented with gypsum, $\mathrm{T}_{3}$ - effluent water mixed with surface water and supplemented with gypsum, $\mathrm{T}_{\mathrm{C}}$ - river water (control). CI - confidence interval (lower and upper bound). Values with the same letter are not significantly different at $p<0.05$

The high salt content in irrigation water creates stressful conditions and negatively affects the mineral metabolism in plants (Subekti et al., 2020). In our experiments, since the salinity level was normal in control, there were no obstacles to the absorption of $\mathrm{P}, \mathrm{K}$ from water. Compared to $T_{1}, T_{2}$, the salt content in $T_{3}$ was lower, however, due to the low $\mathrm{P}, \mathrm{K}$ in $\mathrm{T}_{3}$, the content of $\mathrm{P}$ and $\mathrm{K}$ in the brown seeds may be lower. It should be noted that under stress, the development of the roots decreases, and the absorption of minerals is weakened (Hu and Schmidhalter, 2005; Hakim et al., 2014). In general, in each part of the plant a different amount of mineral accumulates (Sperotto et al., 2017). In other words, the low transportation and accumulation of minerals in $\mathrm{T}_{3}$ can be associated with a high salt content and a low content of P, K. Furthermore, despite the low content of minerals in control, because of optimal regime, there was no interfere to the transportation of minerals.

\section{Conclusion}

Limited water resources, problems with the use of existing water resources, droughts and various global climatic phenomena require the use of alternative irrigation methods. In the current experiment, an analysis of the quality of rice irrigated with water discharged from an intensive fish farm was made. The study showed that both the direct use of intensive fish farm water $\left(T_{1}\right)$ and supplemented with additives $\left(T_{2}, T_{3}\right)$ does not adversely affect TKW and $\mathrm{MC}$ of rice grains (excluding $\mathrm{P}$ and $\mathrm{K}$ during $\mathrm{T}_{3}$ irrigation), but reduces percentage of whole polished rice. Based on general ideas, the influence of direct use of intensive fish farm water $\left(T_{1}\right)$ or supplemented with additives $\left(T_{2}, T_{3}\right)$ on the quality indicators of the studied rice variety (M 488) under conditions of minimizing the harming effects of all the stress factors is stable. Although the most important determining factor 
is the amount of irrigation water and the total number of irrigation applications, to further clarify these conditions and the effect of effluent water on the development of aerobic rice, more quality parameters and more genotypes would be necessary in the upcoming experiments. But effluent water from the intensive African catfish farm could be utilized for irrigation purposes what can hinder the negative effects (mainly nutrient content) of this water for the natural water bodies. Finally, the use of effluent water in a more complex agriculture system, such as agroforestry, can also provide a natural solution for the utilization of effluents and also for the restoration and conservation of natural water resources.

Acknowledgements. This research was financially supported by the Hungarian Ministry of Agriculture (NAIK OD001). The research equipment were renewed in the project of GINOP-2.3.3-15-2016-00042, and supported by OTKA K-125423 and 20430-3/2018/FEKUTSTRAT projects. Marks Ibadzade is a scholarship holder of the Stipendium Hungaricum Programme.

\section{REFERENCES}

[1] Abdelraouf, R. E., Hoballah, E. M. A., Horia, M. A. (2014): Reuse of drainage water of fish ponds in Soybean cultivation under sprinkler irrigation system. - International Journal of plant and soil Science 3(6): 644-658.

[2] Ali, F., Waters, D. L., Ovenden, B., Bundock, P., Raymond, C. A., Rose, T. J. (2019): Heat stress during grain fill reduces head rice yield through genotype dependant increased husk biomass and grain breakage. - Journal of Cereal Science 90: 102820.

[3] Balindong, J. L., Ward, R. M., Rose, T. J., Liu, L., Raymond, C. A., Snell, P. J., Ovenden, B. W., Waters, D. L. (2018): Rice grain protein composition influences head rice yield. Cereal Chemistry 95(2): 253-263.

[4] Billah, K. M. M., Hasan, M. M. M., Jharna, D. D. E. (2017): Effect of salinity on growth and protein content of rice genotypes. - Journal of advances in agriculture 7(2): 1057-1063.

[5] Bongi, G., Loreto, F. (1989): Gas-exchange properties of salt-stressed olive (Olea europea L.) leaves. - Plant physiology 90(4): 1408-1416.

[6] Bouman, B. A. M., Wang, H., Yang, X., Zhao, J., Wang, C. (2002): Aerobic rice (Han Dao): a new way of growing rice in water-short areas. - In: Proceedings of the $12^{\text {th }}$ international soil conservation organization conference (Vol. 26, p. 31), Beijing, China: Tsinghua University Press.

[7] Castaneda, A. R., Bouman, B. A. M., Peng, S., Visperas, R. M. (2003): The potential of aerobic rice to reduce water use in water-scarce irrigated lowlands in the tropics. - In: Bouman, B. A. M., Hengsdijk, H., Hardy, B., Bindraban, P. S., Tuong, T. P., Ladha, J. K. (eds.) Water-Wise Rice Production. Proceedings of a Thematic Workshop on Water-Wise Rice Production, 8-11 April 2002 at IRRI Headquarters in Los Banos, Philippines. International Rice Research Institute, Los Banos, Philippines.

[8] Castillo, E. G., Tuong, T. P., Ismail, A. M., Inubushi, K. (2007): Response to salinity in rice: Comparative effects of osmotic and ionic stresses. - Plant Production Science 10(2): 159-170.

[9] Castro, R. S., Azevedo, C. M. B., Bezerra-Neto, F. (2006): Increasing cherry tomato yield using fish effluent as irrigation water in Northeast Brazil. - Scientia Horticulturae 110(1): 44-50.

[10] Chand, S., Kumar, D. (2018): Farmers' perception on climate change and its management strategies: a micro analysis of Rajasthan. - Indian research journal of extension education 18(3): 49-56. 
[11] Chang, J., Cheong, B. E., Natera, S., Roessner, U. (2019): Morphological and metabolic responses to salt stress of rice (Oryza sativa L.) cultivars which differ in salinity tolerance. - Plant Physiology and Biochemistry 144: 427-435.

[12] Chowdhury, J. A., Karim, M. A., Khaliq, Q. A., Ahmed, A. U., Khan, M. S. A. (2016): Effect of drought stress on gas exchange characteristics of four soybean genotypes. Bangladesh Journal of Agricultural Research 41(2): 195-205.

[13] Clermont-Dauphin, C., Suwannang, N., Grünberger, O., Hammecker, C., Maeght, J. L. (2010): Yield of rice under water and soil salinity risks in farmers' fields in northeast Thailand. - Field Crops Research 118(3): 289-296.

[14] Dela Cruz, N., Khush, G. S. (2000): Rice grain quality evaluation procedures. - In: Singh, R. K., Singh, U. S., Khush, G. S. (eds.) Aromatic Rices. Oxford and IBH Publishing Co. Pvt. Ltd., New Delhi, India, pp. 26-27.

[15] Deressa, T. T., Hassan, R. M., Ringler, C. (2011): Perception of and adaptation to climate change by farmers in the Nile basin of Ethiopia. - The Journal of agricultural science 149(1): 23-31.

[16] Dhankhar, P., Tech, M., Hissar, T. (2014): Rice milling. - IOSRJEN 4: 34-42.

[17] Drechsel, P., Evans, A. E. (2010): Wastewater use in irrigated agriculture. - Irrigation and Drainage Systems 24(1-2): 1-3.

[18] Dresselhaus, T., Huckelhoven, R. (2018): Biotic and abiotic stress responses in crop plants. - Agronomy 8(11): 267.

[19] Fraga, T. I., Carmona, F. D. C., Anghinoni, I., GenroJunior, S. A., Marcolin, E. (2010): Flooded rice yield as affected by levels of water salinity in different stages of its cycle. Revista Brasileira de Ciência do Solo 34(1): 175-182.

[20] Ghosh, B., Ali, Md. N., Gantait, S. (2016): Response of rice under salinity stress: a review update. - Rice Research: Open Access 4: 167.

[21] Hakim, M. A., Juraimi, A. S., Hanafi, M. M., Ismail, M. R., Rafii, M. Y., Islam, M. M., Selamat, A. (2014): The effect of salinity on growth, ion accumulation and yield of rice varieties. - J. Anim. Plant Sci 24(3): 874-885.

[22] Haruvy, N. (1997): Agricultural reuse of wastewater: nation-wide cost-benefit analysis. Agriculture, Ecosystems and Environment 66(2): 113-119.

[23] Hu, Y., Schmidhalter, U. (2005): Drought and salinity: a comparison of their effects on mineral nutrition of plants. - Journal of Plant Nutrition and Soil Science 168(4): 541-549.

[24] International Rice Research Institute (2013): Paddy drying training manual - IRRI rice knowledge bank. - http://www.knowledgebank.irri.org/images/docs/training-manualpaddy-drying.pdf. The Philippines, pp. 51.

[25] Jabran, K., Riaz, M., Hussain, M., Nasim, W., Zaman, U., Fahad, S., Chauhan, B. S. (2017): Water-saving technologies affect the grain characteristics and recovery of fine-grain rice cultivars in semi-arid environment. - Environmental Science and Pollution Research 24(14): 12971-12981.

[26] Jones, J. G. (1990): Pollution from fish farms. - Water and Environment Journal 4(1): $14-$ 18.

[27] Joshi, R., Wani, S. H., Singh, B., Bohra, A., Dar, Z. A., Lone, A. A., Singla-Pareek, S. L. (2016): Transcription factors and plants response to drought stress: current understanding and future directions. - Frontiers in Plant Science 7: 1029.

[28] Kamal, A. S. M., Goyer, K., Koottatep, T., Amin, A. T. M. N. (2008): Domestic wastewater management in South and Southeast Asia: the potential benefits of a decentralised approach. - Urban water journal 5(4): 345-354.

[29] Kato, Y., Katsura, K. (2014): Rice adaptation to aerobic soils: physiological considerations and implications for agronomy. - Plant Production Science 17(1): 1-12.

[30] Khan, M. A., Shaukat, S. S., Khan, M. A. (2009): Growth, yield and nutrient content of sunflower (Helianthus annuus L.) using treated wastewater from waste stabilization ponds. - Pak. J. Bot 41(3): 1391-1399. 
[31] Khush, G. S. (2005): What it will take to feed 5.0 billion rice consumers in 2030. - Plant molecular biology 59(1): 1-6.

[32] Lanthaler, C. (2004): Lysimeter Stations and Soil Hydrology Measuring Sites in Europe: Purpose, Equipment, Research Results Future Development. - Thesis for the degree of Magistra der Naturwissenschaften, Graz.

[33] Lapis, J. R., Cuevas, R. P. O., Sreenivasulu, N., Molina, L. (2019): Measuring head rice recovery in rice. - Methods Mol Biol. 1892: 89-98.

[34] Leesawatwong, M., Jamjod, S., Kuo, J., Dell, B., Rerkasem, B. (2004): Nitrogen fertilizer alters milling quality and protein distribution in head rice. - In: $4^{\text {th }}$ International Crop Science Congress, Brisbane, Australia.

[35] Limjuco, R. P., Quinamot, S. M. V., Guy-Ab Jr., V. L., Cabanero, C. B. (2016): The quality and effect on plant growth of tap water and rainwater in Davao city. - UIC Research Journal 20(2). DOI: $10.17158 / 502$.

[36] Mishra, A. K., Mottaleb, K. A., Khanal, A. R., Mohanty, S. (2015): Abiotic stress and its impact on production efficiency: The case of rice farming in Bangladesh. - Agriculture, Ecosystems \& Environment 199: 146-153.

[37] Muthayya, S., Sugimoto, J. D., Montgomery, S., Maberly, G. F. (2014): An overview of global rice production, supply, trade, and consumption. - Annals of the New York Academy of Sciences 1324(1): 7-14.

[38] Nair, J. (2008): Wastewater garden - a system to treat wastewater with environmental benefits to community. - Water science and technology 58(2): 413-418.

[39] Pinheiro, B. D. S., De Castro, E. D. M., Guimarães, C. M. (2006): Sustainability and profitability of aerobic rice production in Brazil. - Field Crops Research 97(1): 34-42.

[40] Rachmat, R., Thahir, R., Gummert, M. (2006): The empirical relationship between price and quality of rice at market level in West Java. - Indonesian Journal of Agricultural Science 7: 27-33.

[41] Rahimi, A., Rezaei, S., Nouri, H., Aghashiri, A. (2012): Effects of municipal wastewater and zinc fertilizer on yield and yield components of wheat (Triticum aestivum L.) in the Yasouj region of Iran. - International Journal of AgriScience 2(4): 313-319.

[42] Rao, P. S., Mishra, B., Gupta, S. R. (2013): Effects of soil salinity and alkalinity on grain quality of tolerant, semi-tolerant and sensitive rice genotypes. - Rice Science 20(4): 284291.

[43] Reddy, A. M., Shankhdhar, D., Shankhdhar, S. C., Mani, S. C. (2010): Effect of aerobic cultivation on yield, biochemical and physiological characters of selected rice genotypes. - ORYZA - An International Journal on Rice 47(1): 22-28.

[44] Rhodes, D., Nadolska-Orczyk, A. (2001): Plant stress physiology. - In: Encyclopaedia of Life Sciences. Nature Publishing Group, available at: http://www.els.net.

[45] Ruiz-Zarzuela, I., Halaihel, N., Balcázar, J. L., Ortega, C., Vendrell, D., Pérez, T., De Blas, I. (2009): Effect of fish farming on the water quality of rivers in northeast Spain. - Water Science and Technology 60(3): 663-671.

[46] Ryu, H. D., Lim, C. S., Kang, M. K., Lee, S. I. (2012): Evaluation of struvite obtained from semiconductor wastewater as a fertilizer in cultivating Chinese cabbage. - Journal of hazardous materials 221: 248-255.

[47] Singh, N., Kaur, R., Sharma, N., Mahajan, G., Bharaj, T. S. (2012): Changes in yield and grain quality characteristics of irrigated rice (Oryza sativa) genotypes under aerobic conditions. - Indian Journal of Agricultural Sciences 82: 589-95.

[48] Sperotto, R. A., Vasconcelos, M. W., Grusak, M. A., Fett, J. P. (2017): Whole-plant mineral partitioning during the reproductive development of rice (Oryza sativa L.). - Spanish Journal of Agricultural Research 15(2): 17.

[49] Suarez, D. L. (2011): Irrigation water quality assessments. - In: Wallender, W. W., Tanji, K. K. (eds.) Agricultural salinity assessment and management. ASCE Book Series, pp. 343370. doi:10.1061/9780784411698.ch11. 
[50] Subekti, N. A., Sembiring, H., Nugraha, D., Priatmojo, B. (2020): Yield of different rice cultivars at two levels of soil salinity under seawater intrusion in West Java, Indonesia. Biodiversitas Journal of Biological Diversity 21(1).

[51] Tenhaken, R. (2015): Cell wall remodeling under abiotic stress. - Frontiers in plant science 5: 771 .

[52] Toze, S. (2006): Reuse of effluent water - benefits and risks. - Agricultural water management 80(1-3): 147-159.

[53] Vergara, B. S. (1991): Rice plant growth and development. - In: Luh, B. S. (ed.) Rice. Springer, Boston, MA, pp. 13-22.

[54] Wang, B. C., Zhou, J., Wang, Y. C., Zhu, L. C., Teixeira da Silva, J. A. (2006): Physical stress and plant growth. - Floriculture, ornamental and plant biotechnology: advances and topical issues 2: 68-85.

[55] Wu, W., Zhou, L., Chen, J., Qiu, Z., He, Y. (2018): GainTKW: A measurement system of thousand kernel weight based on the android platform. - Agronomy 8(9): 178.

[56] Zhou, H., Yun, P., He, Y. (2019): Rice appearance quality. - In: Bao, J. (ed.) Rice. $4^{\text {th }}$ ed., AACC International Press, pp. 371-383. 